\title{
The Genotyping Resistance Profile of the Pol Gene Detected in Blood of Newly Diagnosed HIV-Positive Men Is Durably Archived in the Gut Whatever the Time of Initiation of CART
}

\author{
Anne Emmanuelle Depincéa, b Elodie Dussert ${ }^{a} \quad$ Delphine Vergnon-Miszczycha ${ }^{a}$ \\ Abdelaye Keita $^{a, f}$ Sylvie Pillet ${ }^{a, c}$ Elisabeth Botelho-Nevers ${ }^{a, d} \quad$ Anne Frésard $^{d}$ \\ Amandine Gagneux-Brunon ${ }^{a, d} \quad$ Frédéric R. Lucht ${ }^{a}$ d $\quad$ Xavier Roblin ${ }^{a}$ e \\ Bruno Pozzetto $^{a, c}$ Stéphane Paul ${ }^{a, b}$ Thomas Bourlet ${ }^{a, c}$ \\ ${ }^{a}$ Groupe Immunité des Muqueuses et Agents Pathogènes - GIMAP EA 3064, CIC 1408, Université de Saint-Etienne, \\ Université de Lyon, and ' ${ }^{2}$ Laboratoire d'Immunologie, 'Service des Agents Infectieux et d'Hygiène, d'Service de \\ Maladies Infectieuses et Tropicales, and 'Service d'Hépato-Gastroentérologie, Centre Hospitalo-Universitaire, \\ Saint-Etienne, France; ${ }^{\mathrm{f}}$ Laboratoire de Bactériologie-Virologie, Institut National de Recherche en Santé Publique \\ (INRSP), Bamako, Mali
}

\section{Keywords}

HIV-1 · Combined antiretroviral therapy · Gut · Genotyping resistance assay

\begin{abstract}
Objective: To evaluate the mutational patterns on the pol gene of the main HIV-1 strain archived in cell genome of 10 chronically infected men according to their clinical and therapeutic history. The genotyping resistance profiles were compared between the first blood plasma available at the time of HIV diagnosis and rectal biopsies and PBMC sampled 1-5 years after the initiation of combined antiretroviral therapy (cART). Methods: HIV-1 RNA and cell-associated HIV-1 DNA were quantified by Abbott Real-Time HIV-1 and Generic HIV ${ }^{\circledR}$ DNA cell (Biocentric) assays. The mutations in protease and reverse transcriptase genes were assessed by the Trugene ${ }^{\circledR}$ assay (Siemens). The $\mathrm{C} 2 \mathrm{~V} 3$ region was amplified to determine the viral tropism. Results: In 9 patients, slight or
\end{abstract}

\section{KARGER}

E-Mail karger@karger.com www.karger.com/int no differences were observed between the 3 resistance profiles. Those mostly detected were related to the resistance to nucleos(t)ide (D67N, L210W, T215A, T69D) and nonnucleoside (K103N, V106I, V179I) inhibitors. In 1 rilpivirine-treated patient, the M230l mutation was detected in PBMC. No change of viral tropism was observed between samples. Conclusion: These data suggest that resistance mutations harbored by the main HIV strain in plasma at the time of diagnosis are durably archived in DNA cells whatever the delay between infection and initiation of therapy in patients well controlled by CART.

(c) 2017 S. Karger AG, Basel

\section{Introduction}

The cellular reservoir is one of the major obstacles to a functional or sterilizing cure of HIV infection. In particular, the gut-associated lymphoid tissue (GALT) har-
(๑) 2017 S. Karger AG, Basel

0300-5526/17/0596-0256\$39.50/0
Prof. Thomas Bourlet

GIMAP EA 3064, Faculté de Médecine J. Lisfranc Campus Santé Innovations, 10 rue de Marandière FR-42270 Saint-Priest en Jarez (France)

E-Mail Thomas.Bourlet@chu-st-etienne.fr 
Table 1. Demographic, immunological, and virological characteristics of the studied population

\begin{tabular}{|c|c|c|c|c|c|c|c|c|c|c|c|}
\hline \multirow{2}{*}{$\begin{array}{l}\mathrm{Pa}- \\
\text { tient }\end{array}$} & \multirow{2}{*}{$\begin{array}{l}\text { Age, } \\
\text { years }\end{array}$} & \multirow{2}{*}{$\begin{array}{l}\text { Clinical } \\
\text { stage }^{\mathrm{a}}\end{array}$} & \multirow{2}{*}{$\begin{array}{l}\mathrm{CD}^{+}{ }^{+} \mathrm{T} \text {-cell } \\
\text { count }^{\mathrm{b}}, \\
\text { cells } / \mathrm{mm}^{3}\end{array}$} & \multirow{2}{*}{$\begin{array}{l}\text { HIV RNA } \\
\text { level }^{\text {b }} \\
\text { logcopies/ } \\
\text { mL }\end{array}$} & \multirow{2}{*}{$\begin{array}{l}\text { HIV } \\
\text { genotype }\end{array}$} & \multirow{2}{*}{$\begin{array}{l}\text { HIV RNA } \\
\text { load } \\
\text { decayc, }^{c} \\
\text { months }\end{array}$} & \multirow{2}{*}{$\begin{array}{l}\text { First-line } \\
\text { treatment }\end{array}$} & \multicolumn{2}{|l|}{ Biopsy } & \multicolumn{2}{|l|}{ PBMC } \\
\hline & & & & & & & & $\begin{array}{l}\text { HIV DNA } \\
\text { level, } \\
\text { logcopies/ } \\
\text { mL }\end{array}$ & $\begin{array}{l}\text { qualitative } \\
\text { HIV RNA } \\
\text { detection }\end{array}$ & $\begin{array}{l}\text { HIV DNA } \\
\text { level, } \\
\text { logcopies/ } \\
\text { mL }\end{array}$ & $\begin{array}{l}\text { qualitative } \\
\text { HIV RNA } \\
\text { detection }\end{array}$ \\
\hline 1 & 30 & B & 248 & 3.91 & B & 6 & FTC TDF EFV & 4.08 & + & 3.23 & - \\
\hline 2 & 56 & A & 843 & 3.45 & $\mathrm{~B}$ & 3 & 3TC ABC ATV & 3.06 & + & 2.41 & - \\
\hline 3 & 54 & $\mathrm{C}$ & 152 & 5.77 & B & 2 & FTC TDF DRV & 4.43 & + & 4.21 & + \\
\hline 4 & 50 & B & 435 & 4.01 & B & 3 & FTC TDF DRV & 3.73 & + & 3.04 & + \\
\hline 5 & 47 & B & 257 & 5.52 & $\mathrm{~B}$ & 3 & FTC TDF DRV & 4.59 & + & 3.40 & - \\
\hline 6 & 68 & $\mathrm{C}$ & 74 & 6.29 & CRF02_AG & 15 & FTC TDF DRV & 3.50 & - & 3.61 & - \\
\hline 7 & 49 & A & 1,025 & 6.35 & $\mathrm{~B}$ & 4 & FTC TDF DRV & 3.78 & + & 2.44 & + \\
\hline 8 & 52 & $\mathrm{C}$ & 14 & 5.43 & B & 5 & FTC TDF DRV & 3.40 & + & 2.93 & + \\
\hline 9 & 58 & $\mathrm{C}$ & 36 & 5.23 & $\mathrm{~B}$ & 4 & FTC TDF DRV & 3.42 & + & 3.26 & + \\
\hline 10 & 64 & $\mathrm{C}$ & 20 & 5.13 & $\mathrm{~B}$ & 4 & FTC TDF DRV & 4 & + & 3.21 & + \\
\hline
\end{tabular}

FTC, emtricitabine; TDF, tenofovir; EFV, efavirenz; 3TC, lamivudine; ABC, abacavir; ATV, atazanavir; DRV, darunavir. ${ }^{\text {a }} \mathrm{CDC}$ classification. ${ }^{\mathrm{b}}$ At the time of HIV diagnosis. ${ }^{c}$ Delay between antiretroviral therapy initiation and the first undetectable viral load value.

bors most of HIV-1 target cells and grows during the first weeks of HIV infection [1]. In the absence of combined antiretroviral therapy (cART), a greater viral genetic diversity in the rectum than in blood has been described, mostly because of a mucosal environment favoring a local replication [2]. It has been largely demonstrated that an early initiation of cART is associated with a smaller and less genetically diverse reservoir [3-5]. Although there is poor evidence of genetic evolution of viral populations under suppressive CART initiated during primary infection, the persistence of HIV archived sequences is observed, probably driven by the homeostatic proliferation of memory T cells [3]. In fact, even if early diagnosis and initiation of cART are highly recommended, most living HIV-infected people were detected positive very late in the course of the infection, before the "test and treat" era and mostly during the chronic phase of their infection [6]. Moreover, for some of them the initiation of cART was delayed compared to the time of diagnosis.

Different resistance to antiretroviral drug profiles of HIV-1 pol sequences are archived in DNA cells of patients who received numerous treatments $[7,8]$. In addition, differences in the resistance profiles have been observed between anatomical sites including the gut, suggesting the participation of intestinal mucosa in HIV genotype selection $[7,9]$. It has also been observed that successive drug-resistant variants selected during nonsuppressive therapy remain archived in the cellular reservoir after long-term suppressive cART [10]. To our knowledge, no data are available on the major HIV strain archived in the rectal reservoir of patients diagnosed during the chronic

Transmitted HIV Strain Durably

Archived in the Gut phase of infection and who received an effective first-line therapy. Moreover, even if it has been previously suggested that the gut mucosal viral reservoir is not the major source of plasma viremia rebound after stopping cART [11], studies dealing with the risk of reactivation of resistant mutated strains from intestinal tissue are also missing.

In this work, our aim was to evaluate the mutational patterns on the pol gene of the main HIV-1 strain archived in the cell DNA of chronically infected men under suppressive cART and diagnosed HIV positive at various stages of infection. The genotyping resistance profiles between the first blood plasma available at the time of HIV diagnosis and rectal biopsies and PBMC sampled 1-5 years after the initiation of cART were compared.

\section{Materials and Methods}

\section{Patients}

An ancillary work of a previous study [12] was conducted in 10 HIV -1 chronically infected consenting men followed up at the Infectious Diseases Department of the University Hospital of SaintEtienne, France. The protocol was reviewed and approved by the national CPP Sud-Est I Ethical Committee. The patients had been under CART for more than 1 but less than 5 years, without any viral escape during this period. Their characteristics are depicted in Table 1. At the time of HIV seropositivity diagnosis (called time zero, T0), stages of clinical infection were A, B, and C for 2, 3 and 5 men, respectively. At T0, the median HIV RNA load in blood plasma was 5.23 (range: $3.45-6.35$ ) $\log _{10}$ copies $/ \mathrm{mL}$. The median delay between blood plasma (T0) and rectal biopsy and PBMC samples (both obtained at T1) was of 47 months (range: 12-158). 
Table 2. Resistance mutations and V3 loop sequences analyzed in blood plasma, PBMC, and rectal biopsy samples

\begin{tabular}{|c|c|c|c|c|c|c|c|c|c|}
\hline \multirow{3}{*}{$\begin{array}{l}\mathrm{Pa}- \\
\text { tient }\end{array}$} & \multirow{3}{*}{$\begin{array}{l}\text { Delay } \\
\text { between } \\
\text { HIV diag. } \\
\text { and therapy, } \\
\text { days }\end{array}$} & \multirow{3}{*}{$\begin{array}{l}\text { Delay } \\
\text { between } \\
\text { genotyping } \\
\text { assays }{ }^{\mathrm{a}} \text {, } \\
\text { months }\end{array}$} & \multirow{3}{*}{$\begin{array}{l}\text { Time with } \\
\text { plasma HIV } \\
\text { RNA <40 } \\
\text { copies/mL, } \\
\text { months }\end{array}$} & \multicolumn{4}{|l|}{$\mathrm{RT} /$ protease gene } & \multicolumn{2}{|l|}{ V3 loop gene } \\
\hline & & & & \multicolumn{3}{|l|}{ resistance mutations } & \multirow{2}{*}{$\begin{array}{l}\text { homology } \\
\%\end{array}$} & \multirow{2}{*}{$\begin{array}{l}\text { homology } \\
\%\end{array}$} & \multirow{2}{*}{$\begin{array}{l}\text { tropism }^{c} \\
\text { RNA/ } \\
\text { biopsy }\end{array}$} \\
\hline & & & & blood RNA ${ }^{\mathrm{a}}$ & rectal biopsy & PBMC & & & \\
\hline 1 & 1,530 & 96 & 90 & $\begin{array}{l}\text { Protease: K20M } \\
\text { M36I D60E I62V } \\
\text { L63P H69Q } \\
\text { RT: V106I V179I }\end{array}$ & $\begin{array}{l}\text { Protease: K20M } \\
\text { M36I D60E I62V } \\
\text { L63P H69Q } \\
\text { RT: V106I V179I }\end{array}$ & $\begin{array}{l}\text { Protease: K20M M36I } \\
\text { D60E I62V L63P H69Q } \\
\text { RT: V106I V179I }\end{array}$ & 98.5 & 80 & R5/R5 \\
\hline 2 & 3,102 & 158 & 155 & $\begin{array}{l}\text { Protease: none } \\
\text { RT: D67N T69D L210W } \\
\text { T215D }\end{array}$ & $\begin{array}{l}\text { Protease: I62V } \\
\text { RT: D67N T69D L210W } \\
\text { T215D }\end{array}$ & $\begin{array}{l}\text { Protease: I62V } \\
\text { RT: D67N T69D L210W } \\
\text { T215D }\end{array}$ & 99 & 76 & R5/R5 \\
\hline 3 & 12 & 31 & 29 & $\begin{array}{l}\text { Protease: I15V } \\
\text { RT: D67N T69D L210W } \\
\text { T215A K101E }\end{array}$ & $\begin{array}{l}\text { Protease: I15V } \\
\text { RT: D67N T69D L210W } \\
\text { T215A K101E }\end{array}$ & $\begin{array}{l}\text { Protease: I15V } \\
\text { RT: D67N T69D L210W } \\
\text { T215A K101E }\end{array}$ & 96 & 71 & R5/R5 \\
\hline 4 & 730 & 76 & 69 & $\begin{array}{l}\text { Protease: L63P } \\
\text { RT: none }\end{array}$ & $\begin{array}{l}\text { Protease: L63P } \\
\text { RT: none }\end{array}$ & $\begin{array}{l}\text { Protease: L63P } \\
\text { RT: none }\end{array}$ & 96.5 & 80 & R5/R5 \\
\hline 5 & 2 & 57 & 54 & $\begin{array}{l}\text { Protease: I62V L63P } \\
\text { RT: none }\end{array}$ & $\begin{array}{l}\text { Protease: I62V L63P A71V } \\
\text { RT: none }\end{array}$ & $\begin{array}{l}\text { Protease: I62V } \\
\text { L63P } \\
\text { RT: none }\end{array}$ & 97 & ND & ND \\
\hline 6 & 6 & 47 & 32 & $\begin{array}{l}\text { Protease: L10I } \\
\text { K20I H69K L89M } \\
\text { RT: none }\end{array}$ & $\begin{array}{l}\text { Protease: } M 36 I \\
\text { H69K L89M } \\
\text { RT: none } \\
\end{array}$ & $\begin{array}{l}\text { Protease: } M 36 I \\
\text { H69K L89M } \\
\text { RT: none }\end{array}$ & 97 & ND & ND \\
\hline 7 & 0 & 12 & 8 & $\begin{array}{l}\text { Protease: L63P I64V } \\
\text { RT: K103N }\end{array}$ & $\begin{array}{l}\text { Protease: L63P I64V } \\
\text { RT: K103N }\end{array}$ & ND & 98.5 & ND & ND \\
\hline 8 & 7 & 44 & 39 & $\begin{array}{l}\text { Protease: } \mathrm{I} 62 \mathrm{~V} \\
\text { RT: none }\end{array}$ & $\begin{array}{l}\text { Protease: I62V } \\
\text { RT: none }\end{array}$ & $\begin{array}{l}\text { Protease: I62V } \\
\text { Q58E A71T } \\
\text { RT: none } \\
\end{array}$ & 96.5 & 78.5 & R5/R5 \\
\hline 9 & 6 & 44 & 40 & $\begin{array}{l}\text { Protease: } M 36 I, \text { I64V } \\
\text { RT: D67N T69D L210W } \\
\text { T215W }\end{array}$ & $\begin{array}{l}\text { Protease: I64V } \\
\text { RT: D67N T69D L210W } \\
T 215 D\end{array}$ & $\begin{array}{l}\text { Protease: I64V } \\
\text { RT: D67N T69D L210W }\end{array}$ & 99.5 & 75.5 & R5/R5 \\
\hline 10 & 3 & 47 & 43 & $\begin{array}{l}\text { Protease: L33V, L63P, I64V } \\
\text { RT: none }\end{array}$ & $\begin{array}{l}\text { Protease: L33V, } \\
\text { L63P, I64V } \\
\text { RT: L210W }\end{array}$ & $\begin{array}{l}\text { Protease: L33V, L63P, } \\
\text { I64V } \\
\text { RT: L210W M230I }\end{array}$ & 96 & 79 & R5/R5 \\
\hline
\end{tabular}

Italics indicate discrepant mutations between samples. ND, not done. ${ }^{a}$ The blood plasma was sampled at the time of HIV seropositivity diagnosis. ${ }^{\mathrm{b}}$ Between RNA and biopsy sequences. ${ }^{c}$ Determined by the Geno2Pheno algorithm.

Total Cell-Associated HIV-1 DNA Quantification

Total DNA was extracted from PBMC and biopsies using the QIAamp DNA Mini Kit (Qiagen, Courtaboeuf, France). The cellassociated HIV-1 DNA was quantified by using the Generic HIV ${ }^{\circledR}$ DNA cell protocol (Biocentric, Bandol, France). The quantification of the glyceraldehyde-3-phosphate dehydrogenase (GAPDH) gene was undertaken to estimate the amount of cells tested. The results were expressed in $\log _{10}$ copies per million of cells.

HIV-1 RNA Viral Load Quantification in Blood Plasma

The viral load was determined by using the Abbott Real-Time HIV-1 Assay (Abbott Molecular Diagnostics, Rungis, France) combining an automated extraction by the m2000sp apparatus and a real-time amplification by the $\mathrm{m} 2000 \mathrm{rt}$ instrument.

\section{Antiretroviral Drug Resistance Mutations Assay}

The antiretroviral drug resistance mutations in protease and reverse transcriptase (RT) genes were assessed in parallel using the Trugene $^{\circledR}$ assay (Siemens, Saint-Denis, France) according to the manufacturer's instructions for RNA (blood samples) omitting the reverse transcription step for DNA (PBMC and biopsy samples). The viral susceptibility to drugs was determined according to the ANRS resistance algorithm (http://www.hivfrenchresistance.org).

\section{Intracellular HIV-1 RNA Detection}

Total RNA was extracted from PBMC and biopsies using RNA Blood Mini and RNeasy kits (Qiagen), respectively. HIV-1 RNA was detected by real-time PCR using the Generic $\mathrm{HIV}^{\circledR}$ assay (Biocentric).

\section{gp120 Gene Amplification and Tropism Determination}

The $C 2 V 3$ coding region was amplified according to the ANRS AC11 Resistance Study Group protocol (http://www.hivfrenchresistance.org). The coreceptor used was predicted using the bioinformatic tool Geno2Pheno with a $10 \%$ false-positive rate and the combined 11/25 and net charge rule for HIV-1 non-B subtypes (http://coreceptor.geno2pheno.org/) [13].

\section{Results}

\section{Efficacy of cART in Blood Compartments}

The median delay between HIV diagnosis (T0) and initiation of cART was 6.5 days (range: $0-3,102$ ). The time to obtain HIV RNA undetectability in blood plas-
Depincé et al. 
ma, defined as the period between initiation of cART and the first viral load value $<40$ copies/mL, was 4 months [2-15]. No viral rebound was observed during the study period except 1 blip in patient 4 at month 18 after starting CART.

\section{HIV RNA and DNA Loads in PBMC and Rectal Biopsies (Sampled at T1)}

Rectal biopsies and PBMC samples were obtained at a median of 47 months (range: 12-158) after HIV diagnosis. The median values of total HIV DNA in the rectum and PBMC were 3.75 (3.06-4.59) and 3.25 (2.41-4.21) $\log _{10}$ copies $/ 10^{6}$ cells, respectively (Table 1 ). HIV RNA was found positive in 9 biopsies and 6 PBMC fractions out of the 10 tested.

\section{Resistance Profiles on Protease and RT Genes from}

Initial Blood and Distant Tissue Samples

The homology between protease and RT sequences from plasma at T0 and rectal tissue at T1 sampled in the same patient ranged from 96 to $99.5 \%$ (Table 2).

The same resistance patterns were obtained in the 3 tested samples for 3 patients. Mutations conferring possible resistance to the protease inhibitors saquinavir/ritonavir and tipranavir (K20M, M36I, I62V, H69Q) and to the nonnucleoside RT inhibitor etravirine (V106I, V179I) were detected in patient 1 . Thymidine analog mutations (TAMs) D67N, L210W, T215A, and T69D conferring resistance to the nucleoside RT inhibitors zidovudine, didanoside, stavudine, abacavir, and tenofovir were detected in patient 3. No mutation, except the L63P minor mutation, was found in patient 4 . The same profiles were also obtained in blood plasma and rectal biopsy of patient 7 (PBMC fraction not available) exhibiting the K103N mutation, conferring a high level of resistance to efavirenz and nevirapine.

In 6 patients, slight differences were observed between resistance profiles: minor L10I, K20I, and/or M36I (patients 6 and 9), I62V (patient 2), Q58E and A71T (patient 8), and A71V (patient 5) mutations in the protease gene. The T215D revertant mutation was detected in the T1 rectal tissue while $\mathrm{T} 215 \mathrm{~W}$ was present in the T0 blood plasma sample of patient 9. The T210W mutation was observed in the biopsy but not in the initial blood sample of patient 10; what is also worthy of note is the presence of the M230I mutation related to resistance to rilpivirine in the PBMC fraction of this patient. This man received 2 successive cART regimens, the current one associating emtricitabine, tenofovir, and rilpivirine.

Transmitted HIV Strain Durably

Archived in the Gut
Sequences of gp120 and Viral Tropism Analysis from

Initial Blood and Distant Tissue Samples

The homology between $\mathrm{C} 2 \mathrm{~V} 3$ coding sequences from T0 plasma and T1 rectal tissue sampled in the same patient ranged from 71 to $80 \%$. No change of viral tropism was observed between the initial blood sample and the rectal biopsy (all being CCR5 tropic).

\section{Discussion}

The rectal mucosa can integrate HIV-1 strains resistant to antiretroviral treatment selected during therapy and participates to the failure to reach optimal local drug concentrations [7, 9, 10]. Josefsson et al. [3] showed that HIV-1 DNA integrated in GALT-infected T cells remains stable during suppressive cART when sequences between plasma sampled at the time of initiation of cART and GALT biopsies obtained 8-12 years after starting therapy were compared. In our study, the resistance pattern of the pol gene in rectal tissue and PBMC - obtained between 12 and 158 months after HIV diagnosis - of men under an effective first-line cART regimen was compared to the one obtained from the first blood plasma sampled at the time of HIV diagnosis. Our data bring complementary information since we found that the transmitted mutational profile present at the time of HIV diagnosis remains stable and detectable after a period of $1-5$ years before and after the start of cART - in 9 out of 10 men, despite a long period without therapy in some men (patient 1 and 2). In addition, intracellular HIV RNA was detected positive in 6 rectal biopsies. This might reflect a local defective viral production rather than a complete replication related to cell-to-cell transmission. Slight differences observed between samples in some patients were for minor mutations on the protease gene not related to the current cART regimen. Interestingly, the only detected resistance mutation potentially related to therapy was M230I conferring resistance to rilpivirine. One explanation could be the moderate rate of diffusion in the rectum of this nonnucleoside RT inhibitor, as recently reported for the long-acting form of this drug [14].

It has been previously demonstrated that no significant evolution of the HIV-1 env gene occurs in PBMC or GALT of people initiating cART during the early phase of HIV infection by using single genome amplification technology [5]. We observed lower percentages of homology in the env than in the pol gene when comparing sequences from the initial plasma sample with those from the PBMC and biopsies (data not shown). However, the estimated

Intervirology 2016;59:256-261 259 
coreceptor usage remained the same (CCR5 in all tested men). In fact, the Sanger technology only detects the main strain and does not allow for deciphering whether the obtained sequences or mutations belong to the same virus. These discrepancies between pol and env genes may also be due, at least in part, to different selective pressures from antiretroviral agents on the pol gene and from the host environment on env. In addition, recombination can occur in env during antiretroviral therapy, contributing to a specific evolution of this gene, as recently described [15]. We also did not find any evidence of archived mutations either in the gut or in PBMC related to the period of decay of viral load after the initiation of cART. This finding is in agreement with Bergroth et al. [16], who did not find any M184V mutation in the plasma of chronically infected patients during the decay period after starting a triple therapy regimen including 3TC. In this study, the archived pol DNA sequences were not explored. These findings suggest that a triple regimen composed of 2 nucleos(t)ide inhibitors and 1 nonnucleoside or 1 protease inhibitor (such as darunavir) that exhibit a high rate of tissue diffusion is able to circumvent the selection of resistance mutations during the first weeks after initiating cART [17].
As a whole, our study conducted in patients diagnosed during the chronic phase of infection demonstrates that the main strain present in blood plasma at the time of diagnosis is durably archived in rectal and PBMC reservoirs, as was shown in PBMC of patients enrolled in the French PRIMO cohort [18]. Even if it has been suggested that the gut reservoir was not the major source of rebound plasma viremia after stopping cART [11], more data are expected on the potential risk of reactivation of archivedresistant strains, especially in the era of the development of HIV cure strategies.

\section{Acknowledgments}

The authors thank all patients who took part in this study and Veronique Ronat for her assistance. This work was supported by grants from the University of Lyon, the University of Saint-Etienne, and Saint-Etienne Metropole.

\section{Disclosure Statement}

The authors declare no conflicts of interest.

\section{References}

1 Ananworanich J, Schuetz A, Vandergeeten C, Sereti I, de Souza M, Rerknimitr R, Dewar R, Marovich M, van Griensven F, Sekaly R, Pinyakorn S, Phanuphak N, Trichavaroj R, Rutvisuttinunt W, Chomchey N, Paris R, Peel S, Valcour V, Maldarelli F, Chomont N, Michael N, Phanuphak P, Kim JH; RV254/SEARCH 010 Study Group: Impact of multi-targeted antiretroviral treatment on gut $\mathrm{T}$ cell depletion and HIV reservoir seeding during acute HIV infection. PLoS One 2012;7:e33948.

2 Avettand-Fenoel V, Hocqueloux L, MüllerTrutwin M, Prazuck T, Melard A, Chaix ML, Agoute E, Michau C, Rouzioux C: Greater diversity of HIV DNA in the rectum compared to variants in the blood in patients without HAART. J Med Virol 2011;83:1499-1507.

3 Josefsson L, Von Stockenstrom S, Faria NR, Sinclair E, Bacchetti P, Killian M, Epling L, Tan A, Ho T, Lemey P, Shao W, Hunt PW, Somsouk M, Wylie W, Douek DC, Loeb L, Custer J, Hoh R, Poole L, Deeks SG, Hecht F, Palmer S: The HIV-1 reservoir in eight patients on long-term suppressive antiretroviral therapy is stable with few genetic changes over time. Proc Natl Acad Sci USA 2013; 110:e4997-e4996.
4 Jain V, Hartogensis W, Bacchetti P, Hunt PW, Hatano H, Sinclair E, Epling L, Lee TH, Busch MP, McCune JM, Pilcher CD, Hecht FM, Deeks SG: Antiretroviral therapy initiated within 6 months of HIV infection is associated with lower T-cell activation and smaller HIV reservoir size. J Infect Dis 2013;208: 1202-1211.

5 Evering TH, Mehandru S, Racz P, TennerRacz C, Poles MA, Figueroa A, Mohri H, Markowitz M: Absence of HIV-1 evolution in the gut associated lymphoid tissue from patients on combination antiviral therapy initiated during primary infection. PLoS Pathog 2012; 8:e1002506.

6 UNAIDS. Report on the global AIDS epidemic 2013. http://www.unaids.org/en/resources/ documents/2013/20130923_UNAIDS_Global_Report_2013.

7 Katzenstein TL, Petersen AB, Storgaard M, Obel N, Jensen-Fangel S, Nielsen C, Jørgensen LB: Phylogeny and resistance profiles of HIV-1 POL sequences from rectal biopsies and blood. J Med Virol 2010;82:1103-1109.

8 van Marle G, Church DL, Nunweiler KD, Cannon K, Wainberg MA, Gill MJ: Higher levels of Zidovudine resistant HIV in the colon compared to blood and other gastrointestinal compartments in HIV infection. Retrovirology 2010;13:74.
9 Monno L, Punzi G, Scarabaggio T, Saracino A, Brindicci G, Fiore JR, Iambrenghi OC, Di Stefano M, Pastore G, Angarano G: Mutational patterns of paired blood and rectal biopsies in HIV-1 infected on HAART. J Med Virol 2003;70:1-9.

10 Verhofstede C, Noë A, Demecheleer E, De Cabooter N, Van Wanzeele F, Van Der Gucht B, Vogelaers D, Plum J: Drug-resistant variants that evolve during nonsuppressive therapy persist in HIV-1-infected peripheral blood mononuclear cells after long-term highly active antiretroviral therapy. J Acquir Immune Defic Syndr 2004;35:473-483.

11 Lerner P, Guadalupe M, Donovan R, Hung J, Flamm J, Prindiville T, Sankaran-Walters S, Syvanen M, Wong JK, George MD, Dandekar $\mathrm{S}$ : The gut mucosal viral reservoir in HIV-infected patients is not the major source of rebound plasma viremia following interruption of highly active antiretroviral therapy. J Virol 2011;85:4772-4782.

12 Depincé-Berger AE, Vergnon-Miszczycha D, Girard A, Frésard A, Botelho-Nevers E, Lambert C, Del Tedesco E, Genin C, Pozzetto B, Lucht F, Roblin X, Bourlet T, Paul S: Major influence of CD4 count at the initiation of cART on viral and immunological reservoir constitution in HIV-1 infected patients. Retrovirology 2016;13:44. 
13 Raymond S, Delobel P, Mavigner M, Cazabat M, Souyris C, Encinas S, Sandres-Sauné K, Pasquier C, Marchou B, Massip P, Izopet J: Genotypic prediction of HIV-1 CRF02-AG tropism. J Clin Microbiol 2009;47:2292-2294.

14 Jackson AG, Else LJ, Mesquita PM, Egan D, Back DJ, Karolia Z, Ringner-Nackter L, Higgs CJ, Herold BC, Gazzard BG, Boffito M: A compartmental pharmacokinetic evaluation of long-acting rilpivirine in HIV-negative volunteers for pre-exposure prophylaxis. Clin Pharmacol Ther 2014;96:314-323.
15 Shi B, Kitchen C, Weiser B, Mayers D, Foley B, Kemal K, Anastos K, Suchard M, Parker M, Brunner C, Burger A: Evolution and recombination of genes encoding HIV-1 drug resistance and tropism during antiretroviral therapy. Virology 2010;15:5-20.

16 Bergroth T, Ekici H, Gisslén M, Loes SK, Goh LE, Freedman A, Lampe F, Johnson MA, Sönnerborg A: Selection of drug-resistant HIV-1 during the early phase of viral decay is uncommon in treatment-naïve patients initiated on a three- or four-drug antiretroviral regimen including lamivudine. J Med Virol 2009; $81: 1-8$.
17 Thompson CG, Cohen MS, Kashuba A. Antiretroviral pharmacology in mucosal tissues. J Acquir Immune Defic Syndr 2013;63:S240S247.

18 Ghosn J, Pellegrin I, Goujard C, Deveau C, Viard JP, Galimand J, Harzic M, Tamalet C, Meyer L, Rouzioux C, Chaix ML; French PRIMO Cohort Study Group (ANRS CO 06): HIV-1 resistant strains acquired at the time of primary infection massively fuel the cellular reservoir and persist for lengthy periods of time. AIDS 2006;20:159-170. 